\author{
Loyalitas Kreativitas \\ Aldi Masyarakat Kreatif
}

P-ISSN 2722-2101, E-ISSN 2722-4201

Program Studi Ekonomi Manajemen Universitas Pamulang Jurnal LOKABMAS Kreatif Vol. 01, No. 01, Hal. 89-95

Email:jurnalkreatif.manajemen@gmail.com

\title{
PENGEMBANGAN POTENSI EKONOMI KEWIRAUSAHAAN IBU RUMAH TANGGA DALAM MENINGKATKAN EKONOMI MASYARAKAT KELURAHAN CEMPAKA PUTIH CIPUTAT
}

\author{
Fahmi Susanti, Derizka Ivanka Jaswita, Sri mardiana \\ Staf Pengajar Fakultas Ekonomi Universitas Pamulang \\ Email: dosen02024@unpam.ac.id
}

\begin{abstract}
ABSTRAK
Pengabdian ini berjudul Pengembangan Potensi Ekonomi Kewirausahaan Ibu Rumah Tangga Dalam Meninngkatkan Ekonomi masyarakat Kelurahan Cempaka Putih Ciputat.

. Tujuan pengabdian ini adalah untuk membantu mengembangkan potensi kewirausahaan ibu rumah tangga di Kelurahan Cempaka Putih Ciputat yang diharapkan dapat memunculkan perubahan sosial dan meningkatkan perekonomian rumah tangga. "Menurut Wisadirana (2004) masuknya wanita dalam pasar kerja atau kerja produktif berpengaruh terhadap kegiatan ekonomi rumahtangga, sehingga terjadi perubahan struktur ekonomi keluarga."

Metode yang digunakan adalah dalam bentuk penyampaian materi (ceramah, tanya jawab interaktif, presentasi ) dan game simulasi mengenai Pengembangan Potensi Ekonomi Kewirausahaan. Kesimpulan dari pengabdian ini adalah peserta penyuluhan kurang memahami secara mendalam tentang potensi kewirausahaan bagi ibu Rumah Tangga.
\end{abstract}

\section{Kata Kunci: Kewirausahaan, Potensi Ekonomi}

\section{ABSTRAC}

This dedication is titled Developing the Economic Potential of Housewife Entrepreneurship in Increasing the Economy of the Community of Cempaka Putih Village, Ciputat. . The purpose of this service is to help develop the entrepreneurial potential of housewives in Ciputat Cempaka Putih Village which is expected to bring about social change and improve the household economy. "According to Wisadirana (2004) the inclusion of women in the labor market or productive work affects household economic activity, resulting in changes in family economic structure."

The method used is in the form of delivery of material (lectures, interactive question and answer, presentations) and simulation games regarding the Development of Economic Potential Entrepreneurship. The conclusion of this dedication is that the extension participants did not understand deeply about the entrepreneurial potential for housewives.

\section{Keywords: Entrepreneurship, Economic Potential}

\section{PENDAHULUAN}

Dengan turut berperannya wanita dalam kegitan ekonomi dalam keluarga akan meebantu meningkatkan status sosial keluarga. Didukung potensi wirausaha yang dimiliki ibu rumah tangga (ibu PKK) kelurahan Cempaka Putih serta sempitnya peluang kerja pada era globalisasi ini mengembangkan keterampilan dan wawasan kewirausahaan sangat penting dalam menumbuh kembangkan jiwa wirausaha. Permasalahan yang ada pada ibu Pkk Kelurahan Cempaka Putih adalah kurangnya pembinaan 


\section{Loyalitas Kreativitas \\ Aldi Masyarakat Kreatif}

P-ISSN 2722-2101, E-ISSN 2722-4201

Program Studi Ekonomi Manajemen Universitas

Pamulang

Jurnal LOKABMAS Kreatif Vol. 01, No. 01, Hal. 89-

95

Email:jurnalkreatif.manajemen@gmail.com

dalam hal pengembangan kewirausahaan ibu rumah tangga, termasuk di dalamnya ibu PKK, dasa wisama,Posyandu dll, belum adanya pengorganisasian manajemen kewirausaahaan yang difokuskan pada ibu ibu rumah tangga yang dapat membantu meningkatkan kualitas ekonomi rumah tangga keluarga, masih sedikit nya kegiatan ekonomi kemasyarakatan, masalah lainnya adalah masih sedikitnya bantuan dari pemerintah dalam pengembangan potensi kewirausahaan berupa bantuan peralatan ataupun pelatihan pelatihan. Bantuan stimulant telah diberikan oleh Departemen Perdagangan kepada ibu PKK kelurahan Cempaka Putih adalah berupa bantuan peralatan masak yang diharapkan dapat menunjang potensi kewirausahaan dari ibu PKK Cempaka Putih Ciputat yaitu keterampilan dalam bidang kuliner (catering atau pemesanan makanan). Namun meskipun sudah ada nya bantuan berupa peralatan masak, bantuan tersebut masih dirasakan kurang dan belum bisa membantu peningkatan kualitas perekonomian keluarga secara signifikan. Masih banyak potensi kewirausahaan yang harus digali pada ibu -ibu PkK ini, pengembangan potensi kewirausahaan pengembangan jiwa kewirausaahaan dapat menjadi solusi. Jika dibekali pengelolaan manajemen tentang pemasaran, strategi pemasaran, pengelolaan tempat, pengelolaan kemampuan berfikir untuk berjiwa kreatif, inovatif dan ulet, maka diharapkan ibu- ibu PKK dapat menganalis berbagai peluang usaha. Kemampuan kewirausahaan sangat diperlukan oleh setiap pribadi yang menginginkan keadaan masa depan yang lebih bik lagi. Terdapat beberapa keterampilan kemampuan yang harus diketahui dan diaplikasikan oleh Ibu PKK dalam mendukung keberhasilan potensi kewirausahaan antara lain ;

1. Kompetensi atau skill dalam bidang usaha yang akan dilakukan. Keterampilan dan pengetahuan yang mendalam atau harus benar-benar menguasai

bidang usaha tersebut, baik dari teknis pembuatan, teknis pengolahan, teknis perolehan bahan baku, teknis penyajian.

2. Kompetensi Pemasaran: yaitu keterampilan dalam mencari pasar untuk menjual barang hasil produksi, keterampilan menentukan pangsa pasar, keterampilan melihat kecendrungan permintaan konsumen /pasar sehingga sesuai dengan keinginan pasar saat ini.keterampilan dalam menentukan harga saing.

3. Kompetensi keuangan, modal yaitu : keterampilan

Membuat pelaporan dan pembukuan, keterampilan mengolah mengatur pengeluaran, keterampilan menghitung keuntungan, keterampilan mencari modal / investasi,

4. Keterampilan menjalin hubungan kerjasama dengan partner bisnis. Hubungan personal dalam melakukan kemitraan.

Penyuluhan potensi kewirausahaan pada Kelurahan Cempaka Putih ini mencakup :

1. Motivasi, meningkatkan semangat dan membangun percaya diri pada ibu ibu PKK kan potensi 


\section{Loyalitas Kreativitas \\ Aldi Masyarakat Kreatif}

P-ISSN 2722-2101, E-ISSN 2722-4201

Program Studi Ekonomi Manajemen Universitas

Pamulang

Jurnal LOKABMAS Kreatif Vol. 01, No. 01, Hal. 89-

95

Email:jurnalkreatif.manajemen@gmail.com

kewirausahaan yang mereka miliki.

2. Penyadaran, yaitu membantu ibu-ibu PKK untuk menyadari akan masalah masalah yang ada, menyadari dan menangkap peluang serta kesempatan memnafaatkan kesempatan untuk membuka usaha, menyadari pentingnya kekuatan kerjasama teamwork dan menyadari apa saja sumberdaya yang tersedia saat ini.

3. Memperkuat semangat untuk mencapai prestasi dalam berwirausaha.

Dalam penyuluhan dan pelatihan pengembangan potensi kewirausahaan ini membahas bentuk wirausaha yang saesuai dengan kompetensi ibu ibu PKK dan disesuaikan dengan sumber daya yang ada., menggali potensi kewirausahaan yang lain selain keterampilan memasak yang dimiliki oleh ibu-ibu PKK kelurahan Cempaka Putih Ciputat, sehingga berani untuk menjadi sorang wirausaha pemula/ star up. Kompetensi yang ada dikelurahan ini adalah keterampilan memasak dan keterampillan membuat kue. Selain tujuan yang telah disebutkan diatas tujuan yang didapat dari kegiatan penyuluhan ini adalah mendorong terkomersialisasi produk produk hasil produksi ibu-ibu PKK . ( makanan tradisional, makanan untuk pesta). Pada kegiatan pelatihan ini Ibu-Ibu PKK dibimbing untuk belajar membuat proposal bisnis yang benar. Yang bermanfaat untuk menjalin kemitraan bisnis dan pengembangan usaha enterpreuner yang akan menghasilkan aksi dari berbagai actor dan investor sehingga potensi kewirausahaan dapat berkembang dan terkomersialisasi.

Menurut "Hasbullah dkk (2014) permasalahan umum yang dihadapi wirausaha/ tenant di Indonesia dalam pengembangan usahanya antara lain adalah terbatasnya pendanaan untuk pengembangan usaha, kurangnya informasi dan akses bahan baku dan pasar, rendahnya kualitas sumber daya manusia, rendahnya kemampuan untuk menghasilkan produk yang inovatif, dan lemahnya pendampingan ". Sejalan dengan pendapat "Prawiranegara dalam Suryanita (2006) usaha kecil dan menengah masih banyak kendalakendala yang dihadapi yaitu kendala intern yang dihadapi pengusaha kecil adalah kualitas Sumber Daya manusia yang masih rendah, lemahnya akses dan pengembangan pangsa pasar, lemahnya permodalan, teknologi lemah, organisasi manajemen dan kerjasama yang terbatas." Fenomena ini sesuai dengan permasalahan di Kelurahan Cempaka Putih. Untuk memotivasi pengembangan kewirausahaan yang mempunyai kedudukan strategis agar dapat berkembang mengikuti dinamika era globalisasi, perlu di berikan bimbingan, pendampingan, arahan, pelatihan dan sosialisasi. Menurut " Djamal dalam Suparwoto, (2010) diperlukan suatu upaya untuk menyusun model pendampingan wirausaha/tenant berbasis teknologi yang ideal, efektif dan berkelanjutan." Proses kegaitan pendampingan terdiri dari orientasi, persiapan sosial, pengorganisasian kelompok, merencanakan program, pelaksanaan usaha/kegiatan, monitoring/ evaluasi. 


\section{Loyalitas Kreativitas \\ Aldi Masyarakat Kreatif}

P-ISSN 2722-2101, E-ISSN 2722-4201

Program Studi Ekonomi Manajemen Universitas

Pamulang

Jurnal LOKABMAS Kreatif Vol. 01, No. 01, Hal. 89-

95

Email:jurnalkreatif.manajemen@gmail.com

\section{METODE PELAKSANAAN}

Metode yang dilakukan tim PKM dalam pelaksanaan kegiatan pengabdian ini dilakukan dalam beberapa kegiatan yaitu : tahap survey, tahap sosialisasi koordinasi, dan tahap pelaksanaan kegiatan. Subjek kegiatan PKM adalah ibu-ibu PKK kelurahan Cempaka Putih Ciputat. Pelaksanaan kegiatan dilakukan selama 3 hari yaitu pada tanggal 22september 2018 sampai dengan 24 September 2018 Tahap kegiatan pertama (Tahap survei ) yaitu sosialisasi dilakukan dengan menyusun berbagai kegiatan yang akan disampaikan pada saat pelaksanaan kegiatan pengabdian Kepada Masyarakat (PKM) yang meliputi: menyusun pokok bahasan materi yang akan diberikan, penyusunan jadwal pemberian materi selama 3 hari, pembagian tugas tim pengabdian (PKM) dan pra survei ke lokasi pengabdian. Pada Tahap sosialisasi yaitu sebelum kegiatan pengabdian dil aksanakan terlebih dahulu dilakukan silaturahmi dan izin melaksanakan kegiatan PKM dengan Lurah Cempaka Putih Ciputat, untuk menyampaikan maksud dan tujuan dari pengabdian (PKM) ini. Pada tahap ini dilakukan juga koordinasi dengan pihak kelurahan dalam menentukan jadwal dan kegiatan pengabdian, metode yang akan digunakan dalam kegiatan, dan penentuan peserta penyuluhan. Tim pelaksana kegiatan pengabdian (PKM) pada masyarakat adalah dosen Fakultas Ekonomi Program Studi manajemen sebanyak 11 orang, mahasiswa universitas Pamulang sebanyak 3 orang, Staf Universitas Pamulang sebanyak 2 Orang, alumni Universitas Pamulang sebanyak 2 orang. Tim pengabdian memberikan materi

berjudul

\section{"PENGEMBANGAN POTENSI EKONOMI KEWIRAUSAHAAN IBU RUMAH TANGGA DALAM MENINGKATKAN EKONOMI MASYARAKAT KELURAHAN CEMPAKA PUTIH CIPUTAT “}

Kegiatan Pengabdian Kepada Masyarakat dilakukan pada Ibu PKK Kelurahan Cempak Putih Ciputat yang yang berlokasi di Kampung Utan Jl. Jambu No 47 Rt 07/05 Ciputat Tangerang Selatan.Tangerang Selatan 15416.

\section{HASIL DAN PEMBAHASAN}

Kegiatan Pengabdian kepada Masyarakat (PKM) Universitas Pamulang yang dilakukan oleh 11 orang dosen program studi Manajemen telah berjalan dengan lancar dan mendapat sambutan hangat dan sukacita dari tempat pelaksanaan kegiatan ini yaitu di Ibu PKK Kelurahan Cempak Putih Ciputat yang yang berlokasi di Kampung Utan Jl. Jambu No 47 Rt 07/05 Ciputat Tangerang Selatan.

Dari hasil survey dan wawancara salah satu usaha mikro kewirausahaan yang sudah ada di kelurahan Cempaka Putih adalah usaha Catering, dimana pelaku usahanya adalah ibu-ibu Rumah tangga kelurahan Cempaka Putih namun usaha ini perkembangannya belum berjalan dengan signifikan, terkendala dengan promosi pemasaran, manajemen pengelolaan dan modal.

Kegiatan pada hari pertama yaitu 22 September 2018 adalah penyuluhan berbagi wawasan mengenai Peran kewirausahaan dan permasalahan permasalahannya. Isi materi tersebut adalah kewirausahaan mempunyai andil/peran dalam meningkatkan pendapatan daerah, berperan sebagai 


\section{Loyalitas Kreativitas \\ Aldi Masyarakat Kreatif}

P-ISSN 2722-2101, E-ISSN 2722-4201

Program Studi Ekonomi Manajemen Universitas

Pamulang

Jurnal LOKABMAS Kreatif Vol. 01, No. 01, Hal. 89-

95

Email:jurnalkreatif.manajemen@gmail.com

roda penggerak, berperan sebagai inovator dalam perekonomian, serta berperan sebagai penyerap tenaga kerja sejalan dengan pendapat Slamet (2014). Perlu diketahui bahwa usahausaha kecil merupakan kegiatan masyarakat yang mayoritas pada negara berkembang, usaha kecil tersebut telah menyumbangkan kontribusi yang signifikan terhadap peningkatan pendapatan. Sebagai contoh adalah pertumbuhan ekonomi di Negara Indonesia yag dipengaruhi oleh dinamika kegiatan perekonomian daerah yaitu didominasi kegiatan perekonomian berskala kecil dan berskala menengah .Maka dapat diketahui begitu besarnya peran wirausaha . "Menurut Daryanto (2013) lima puluh persen dari usaha kecil gagal pada tahun kedua pelaksanaan dan manajemen yang buruk adalah penyebab terbesar kegagalan usaha kecil." Permasalahan dan kendala-kendala tersebut dialami juga pada kelurahan Cempaka Putih diantaranya kualitas sumber daya manusia yang masih rendah, lemahnya akses dan perkembangan pasar, lemahnya permodalan, teknologi, organisasi dan manajemen serta kerjasama yang terbatas.

Kegiatan pada hari kedua 23 September 2018, mengenai orientasi manajemen kewirausahaan. Wirausaha harus memiliki pondasi dan orientasi manajemen kewirausahaan yang komperhensif agar tetap eksis dan tumbuh sesuai dengan era globalisasi. Pemilihan strategi yang tepat dalam kegiatan usaha merupakan hal penting dan menjadi peranan yang penting untuk tercapainya tujuan sehingga dapat tetap eksis dan bertahan dalam persaingan yang semakin ketat. Telah disebutkan bahwa apabila pelaku usaha mempunyai kompetensi orientasi Manajemen dan menguasai diharapkan pelaku usaha dapat melakukan pengelolaan usaha dengan efektif dan efisien, dimulai dari penyusunan strategi yang sesuai dengan keadaan internal dan eksternal ( Sumber Daya Manusia, sumber daya modal, keadaan pasar, dsb). Sebagai salah satu contoh strategi dalam pemasaran adalah memberikan harga yang lebih murah dibanding harga yang diberikan pesaingnya / competitor. Selanjutnya contoh dari strategi relasi hubungan kerjasama dengan pengusaha lain adalah kerjasama yang didasari oleh kepercayaan, kepuasan dan komitmen yang telah disepakati. Konsep yang menjadi dasar dalam hubungan kerjasama yaitu kepercayaan, kepuasan dan komitmen diantara pengusaha yang menjalin kerjasama.

Kegiatan pada hari ketiga 24 September 2018 .Disampaikan pula akan pentingnya kreativitas dan inovatif. Kreatifitas adalah membuat sesuatu produk yang bebeda dari produk yang sudah ada. Inovatif adalah pelaksanaan dari gagasan gagasan baru. Pada kegiatan ini diharapkan kreatifitas dan inovatif dapat diterapkan pada produk catering kelurahan Cempaka Putih. Ibu PKK harus kreatif dalam teknologi produk baik dalam kemasan, tampilan, rasa. Ibu PKK Kelurahan Cempaka Putih selaku pelaku kewirausahaan harus mampu mencari informasi dan peluang kesempatan untuk meningkatkan kualitas catering yang diproduksi.

Besar pengharapan kami dengan kegiatan pengabdian ini dapat membuka wawasan dan membentuk / bentuk wirausaha yang sesuai dengan kompetensI ibu ibu PKK dan disesuaikan dengan sumber daya 


\section{Loyalitas Kreativitas \\ Aldi Masyarakat Kreatif}

P-ISSN 2722-2101, E-ISSN 2722-4201

Program Studi Ekonomi Manajemen Universitas

Pamulang

Jurnal LOKABMAS Kreatif Vol. 01, No. 01, Hal. 89-

95

Email:jurnalkreatif.manajemen@gmail.com

yang ada., menggali potensi kewirausahaan yang lain selain keterampilan memasak yang dimiliki oleh ibu-ibu PKK kelurahan Cempaka Putih Ciputat, sehoingga berani untuk menjadi seorang wirausaha pemula/ star-up, dan mendorong terkomersialisasi produk produk hasil produksi ibu-ibu PKK.

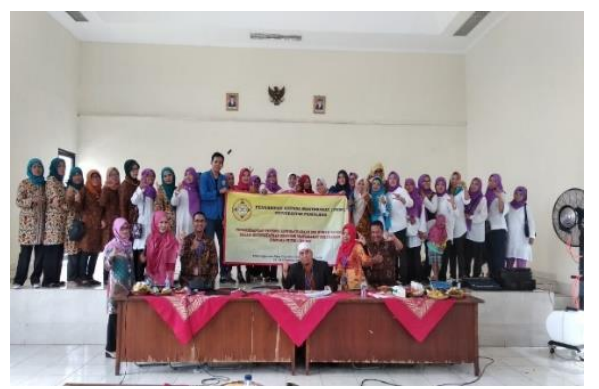

Tim PKM dan Mahasiswa berfoto Bersama dengan Ibu - Ibu PKK serta Lurah dan Ketua PKK Cempaka Putih

Penyerahan Plakat (Kenang-kenangan) dari Tim Pengabdian Dosen Fakultas Ekonomi Prodi Manajemen UNPAM yang diwakili oleh Ketua Pengabdi Baliyah Munadjat, SE.,MM kepada Lurah Kecamatan Cempaka Putih, Ciputat Tangerang Selatan Tarmizi,S.Ag.,MM

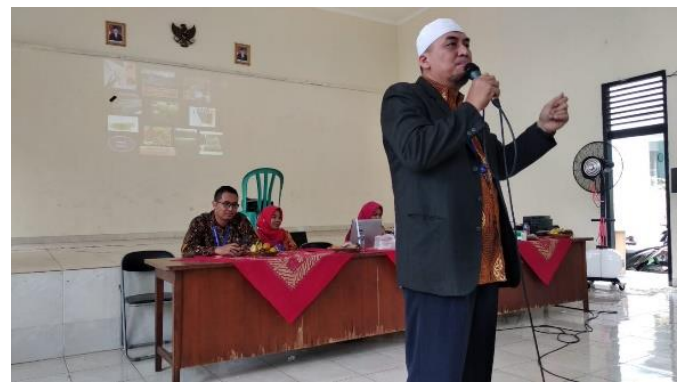

Tim PKM memberikan materi, setelah dilakukakan Pembukaan Kegiatan oleh Lurah Cempaka Putih Ciputat Tangerang Selatan

Penyampaian Materi Pada Hari Pertama (1) Pembicara adalah Hamdi Supriadi,SHI.,MM . Agrasadya SE., MM
dan,Fahmi susanti SKM., MM dan dibantu oleh tim PKM lainnya.

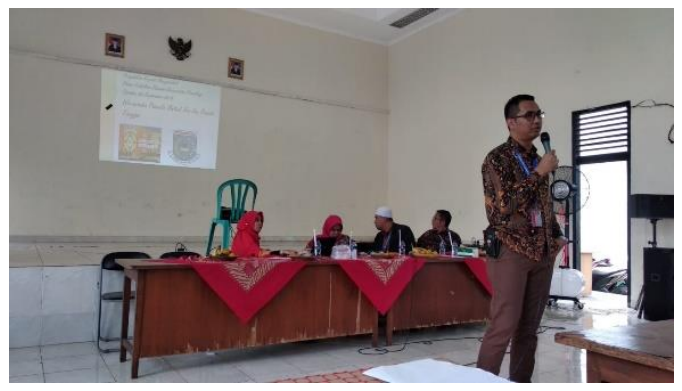

Pemberian Materi Kreativitas dan Inovasi, Pada hari Ketiga (3) kepada ibu ibu Pkk Cempaka Putih Bentuk Pemberian Materi hari ketiga adalah " Game ".Ibu Ibu PKK sedang semangat mengikuti "Game"

\section{KESIMPULAN DAN SARAN \\ Kesimpulan}

Berdasarkan hasil diskusi dan Game simulasi yang telah dilakukan dapat disimpulkan bahwa ibu-ibu PKK Cempaka Putih Cipitutat sudah memahami tentang Pengembangan potensi kewirausahaan bagi ibu Rumah Tangga serta memahami manajemen kewirausahaan.

\section{Saran}

Perlu dibentuknya wadah untuk kegiatan kewirausahaan Kelurahan Cempaka Putih Ciputat sehingga dapat mewujudkan peran Kewirausahaan sebagai pendorong pertumbuhan ekonomi Kelurahan Cempaka Putih Ciputat.

\section{DAFTAR PUSTAKA}

Andriani, Suryanita, 2006. Analisis Pengaruh Kewirausahaan dan Kompetensi Pengetahuan Terhadap kapabilitas Untuk Meningkatkan Kinerja Pemasaran .Tesis. Universitas Diponegoro,Semarang

Aini,N, Slamet dan Bowo,S. (2014) Perbandingan Hasil Belajar Biologi Strategi Pembelajaran Aktif Tipe Make A Match dan Card Sort, Jurnal Bio-Pedagogi 3(1):23-28. 


\section{Loyalitas Kreativitas \\ Aldi Masyarakat Kreatif}

P-ISSN 2722-2101, E-ISSN 2722-4201

Program Studi Ekonomi Manajemen Universitas

Pamulang

Jurnal LOKABMAS Kreatif Vol. 01, No. 01, Hal. 89-

95

Email:jurnalkreatif.manajemen@gmail.com

Daryanto, (2013). Inovasi Pembelajaran Efektif. Bandung

Hasbullah,surahman, M Yasin A Almada P.D \& Faizaty E.N. (2014) Mode Pendampingan UMKM Pangan Melalui Inkubator Bisnis Perguruan Tinggi..Jurnal Ilmu Pertanian (JIPI);Vo 247264.

Pasaribu, V. L. D., Agrasadya, A., Shabrina, N., \& Krisnaldy, K. (2020). MENJADI ENTERPRENEUR MUDA YANG MEMILIKI JIWA LEADERSHIP UNTUK MENGHADAPI MASA DEPAN. Abdi Laksana, 1(1)

Pasaribu, V. L. D., Elburdah, R. P., Sudarso, E., \& Fauziah, G. (2020). PENGGUNAAN MANAJEMEN WAKTU TERHADAP PENINGKATAN PRESTASI BELAJAR DI SMP ARAISIYAH. Jurnal ABDIMAS, 1(1)

Pasaribu, V. L. D., Susanti, F., \& Hartuti, E. T. K. (2019). MEMOTIVASI SISWA DAN SISWI SMK LETRIS INDONESIA DI DALAM MENENTUKAN PILIHAN UNTUK MELANJUTKAN PENDIDIKAN ATAU BEKERJA SETELAH LULUS SEKOLAH. Jurnal Pengabdian Dharma Laksana, 1(2), 161172.

Suparwoto, (2010). Model Pembelajaran Terpadu. Abumi Aksara. Jakarta

http;//jurnal.untidar.ac.id/index.php/REP . Jurnal REP. Arif barata sakti,Anjdjar

Prasetyo. Potensi Peningkatan Produktivitas kewirausahaan Berbasis Model Penguatan Teknopreuner Pada Hasil Inovasi di Kota Magelang. Vol 3 No 1. P-ISSN:2541-433X . E-ISSN: 25080205.

https :// core.ac.ukdownload,pdf diakses 6 oktober 2018
Jurnal

Proceeding, Seminar Nasional PESAT 2005 auditorium Universitas Gunadarma, Jakarta, 23-24 Agustus 2005, ISSN 18582559, Menggali Potensi Kewirausahaan Masyarakat Betawi Di Sawangan, Nilam Widyarini Hendro Prabowo

Jurnal REP Riset Ekonomi Pembangunan volume 3 No 1

http//jurnal.untidar.ac.id/index.php/REP, Potensi Peningkatan Produktivitas Kewirausahaan Berbasis Modul PenguatanTeknoenterpreuner Pada hasil Inovasi Di Kota MAgelang, Arif Bratasakti Anjar Prasetyo

Lutfi Koto. 2015. Motivasi Kewirausahaan mahasiswa Jurusan Administrasi Pendidikan Universitas Negeri Padang.
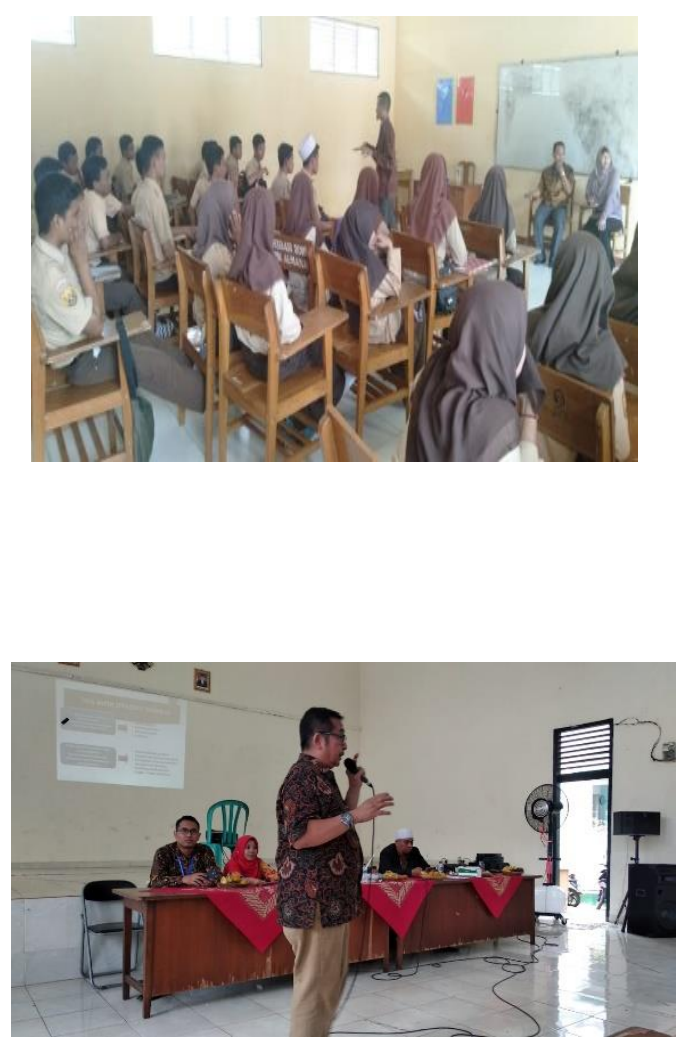


\section{Loyalitas Kreativitas}

Aldi Masyarakat Kreatif
P-ISSN 2722-2101, E-ISSN 2722-4201

Program Studi Ekonomi Manajemen Universitas

Pamulang

Jurnal LOKABMAS Kreatif Vol. 01, No. 01, Hal. 89-

95

Email:jurnalkreatif.manajemen@gmail.com

Penyampaian Materi Pada Hari kedua (2 ) pada Ibu-ibu PKK Cempaka Putih Ciputat . Adapun Tema yang diberikan adalah Manajemen Kewirausahaan . Pembicara adalah P. Ade SE., MM , Hamdi, Sri Mardiana,SE.,MM, Rio setiawan,SE.,MM dan Derizka SE., MM dan dibantu oleh tim PKM lainnya. 